\title{
Stimulation of colorectal cancer cell line growth by ET-1 and its inhibition by $\mathrm{ET}_{\mathrm{A}}$ antagonists
}

\author{
H Ali, M Loizidou, M Dashwood, F Savage, C Sheard, I Taylor
}

\begin{abstract}
Background-The vasoactive peptide endothelin 1 (ET-1) acts via two receptors, endothelin receptors $A\left(E T_{A}\right)$ and $B\left(E T_{B}\right)$. ET-1 is overexpressed by human cancers in vivo and in vitro and may be mitogenic for cancer cells.

Method-To elucidate if ET-1 is a growth regulator the following were investigated in human colorectal cancer cell lines (LIM1215 and HT29): ET-1 production by ELISA; ET receptor expression using radioligand autoradiographic techniques; and responsiveness to ET-1, and to $E_{A}$ and $\mathrm{ET}_{\mathrm{B}}$ antagonism by growth measurements.

Results-ET-1 was produced by LIM1215 and HT29 cells $\left(21.3\right.$ and $41.7 \mathrm{fmol} / \mathrm{ml} / 10^{6}$ cells ( 24 hours); 22.6 and $71.7 \mathrm{fmol} / \mathrm{ml} / 10^{6}$ cells (48 hours), respectively). ET $_{\mathrm{A}}$ and $\mathrm{ET}_{\mathrm{B}}$ receptors were expressed by both cell lines. Addition of ET-1 resulted in a dose dependent increase in cell numbers which was significant at $10^{-8}-10^{-9} \mathrm{M}$ for LIM1215, with the greatest increase at $10^{-8} \mathrm{M}(32.7 \%$ and $28.4 \%$ increase above controls at 48 hours and 72 hours; $p<0.05$ ) and at $10^{-8}-10^{-9} M$ for HT29, with the greatest increase at $10^{-9} \mathrm{M}(13.4 \%$ and $15.7 \%$ increase above controls at 48 hours and 72 hours; p<0.05). ET $\mathrm{A}_{\mathrm{A}}$ antagonists BQ123 and $B Q 610$, but not the $\mathbf{E T}_{\mathrm{B}}$ antagonist BQ788, inhibited ET-1 induced proliferation of both LIM1215 and HT29 $(p<0.05)$. Conclusion-ET-1 can stimulate the proliferation of colorectal cancer cell lines via the $\mathrm{ET}_{\mathrm{A}}$, but not the $\mathrm{ET}_{\mathrm{B}}$, receptor. (Gut 2000;47:685-688)
\end{abstract}

Keywords: endothelin-1; endothelin receptor; colorectal cancer; colorectal cancer cell lines

C Sheard

I Taylor

Departments of Molecular Pathology and Clinical

Biochemistry, and Surgery, Royal Free and University College Medical School,

London, UK

M Dashwood

Correspondence to: Professor I Taylor, Department of Surgery, Royal Free and University College Medical School, Charles Bell House, 67-73 Riding House Street, W1P 7LD, London UK. m.loizidou@ucl.ac.uk

Accepted for publication 9 May 2000

The endothelins are a family of 21 amino acid peptides. There are three members in the endothelin family: endothelin 1, 2, and 3 (ET-1, ET-2, and ET-3). These peptides act via the $G$ protein coupled to receptor subtypes A $\left(\mathrm{ET}_{\mathrm{A}}\right)$ and $\mathrm{B}\left(\mathrm{ET}_{\mathrm{B}}\right) ; \mathrm{ET}-1$ and $\mathrm{ET}-2$ bind to $\mathrm{ET}_{\mathrm{A}}$ with a higher affinity than ET-3 and all isopeptides display similar affinities for $\mathrm{ET}_{\mathrm{B}}{ }^{1-3}$ ET-1 was first isolated from porcine aortic endothelial cells and has potent vasoactive activity. ${ }^{4}$ However, ET- 1 is now recognised as having multiple pathophysiological activities, including mitogenesis. ${ }^{5-7}$ Increased ET-1 levels have been detected in plasma and tissue samples from patients with solid malignant tumours, including liver, lung, prostate, and breast cancers. ${ }^{8-12}$ ET- 1 is also produced in vitro by several cancer cell lines, including colonic, pancreatic, ovarian, breast, stomach, and prostate. ${ }^{13-16}$ Shichiri and colleagues have proposed that ET-1 acts as an autocrine growth factor. ${ }^{17}$ Specifically in ovarian cancer cells, ET-1 has been shown to give an autocrine mitogenic stimulus via the $\mathrm{ET}_{\mathrm{A}}$ receptor. ${ }^{18}$

In colorectal cancer, raised levels of ET-1 have been detected in the plasma of patients with and without metastasis to the liver. Furthermore, ET-1 has been demonstrated immunohistochemically in tumour epithelial cells, stroma, and the blood vessels of both primary colorectal cancer and liver metastases. ${ }^{19-21}$ Autoradiographic studies have detected the presence of binding sites (putative receptors) for ET-1 in colorectal cancer specimens and normal tissue, including the nerve supply of the colon. ${ }^{22-24}$ Although colorectal cancer cells have been shown to secrete ET-1 in vitro, it is not known if this peptide acts as a mitogen for these cells.

The aims of our study were to investigate: firstly, the production of ET-1 and expression of $\mathrm{ET}_{\mathrm{A}}$ and $\mathrm{ET}_{\mathrm{B}}$ receptors by two colorectal cancer cell lines; secondly, the ability of ET-1 to stimulate the proliferation of these cell lines; and finally, the potential of ET receptor antagonism as an inhibitor of growth.

\section{Materials and methods}

The human colorectal cancer cell lines HT29 (ECACC, Salisbury, Wiltshire, UK) and LIM1215 (kindly donated by Dr M O'Hare, Ludwig Institute for Cancer Research, London, UK) were used. The cells were routinely cultured at $37^{\circ} \mathrm{C}$ with $5 \% \quad \mathrm{CO}_{2}$ in 95\% air in Dulbecco's modified Eagle medium (DMEM), supplemented with $10 \%$ fetal calf serum (FCS), L-glutamine $2 \mathrm{mM}$, penicillin $100 \mathrm{IU} / \mathrm{ml}$ and streptomycin $100 \mu \mathrm{g} / \mathrm{ml}$ (all from Imperial Laboratories, Basingstoke, Hants, UK).
ET-1 PRODUCTION

Cells were plated to obtain $85-90 \%$ confluence by 72 hours. They were seeded and left to grow in $10 \%$ FCS containing medium for the first 24 hours. This was replaced by serum free medium and supernatants were collected after 24 and 48 hours and stored at $-70^{\circ} \mathrm{C}$ until assayed. At each time point, the number of cells were counted on a haemocytometer in order to relate production of ET-1 to cell numbers. ET-1 in the media was measured using an ET-1 kit for an ELISA (Nycomed Amersham, Little Chalfont, Buckinghamshire, UK) and the

Abbreviations used in this paper: ET, endothelin; $\mathrm{ET}_{\mathrm{A}}$, endothelin receptor $\mathrm{A} ; \mathrm{ET}_{\mathrm{B}}$, endothelin receptor B; DMEM, Dulbecco's modified Eagle medium; FCS, fetal calf serum; PBS, phosphate buffered saline. 
absorbance read at $550 \mathrm{~nm}$ on a plate reader (MRX Denley, Billinghurst, West Sussex, UK). Baseline readings of ET-1 were provided by assaying serum free DMEM. The assay has a sensitivity of 1-32 fmol per well for a 96 well plate and specificity of $98 \%$ for ET- 1 ; cross reactivity with ET-2 is $<2 \%$, and with ET-3 $<0.01 \%$

\section{ENDOTHELIN RECEPTOR EXPRESSION}

Cultured cells were trypsinised and cytospins were prepared using $10^{6}$ cells per spot. The slides were incubated with $150 \mathrm{pM}{ }^{125} \mathrm{I}$ ET-1 (specific activity $2000 \mathrm{Ci} / \mathrm{mM}$ ) and nonspecific binding was determined by coincubation of alternate slides with $500 \mathrm{nM}$ unlabelled ET-1 at room temperature. After incubation, cells were dried and autoradiographs generated by apposing to Hyperfilm ${ }^{3} \mathrm{H}$ (Nycomed Amersham) for up to eight days. Film was processed according to the manufacturer's instructions and cells were stained with haematoxylin and eosin for histology. Cellular binding was achieved by post fixing incubated cells with paraformaldehyde vapour $\left(80^{\circ} \mathrm{C}\right.$ for two hours), coating them with molten nuclear emission (Ilford K2, Mobberly, Cheshire, UK), and exposing them for eight days, after which emulsion was processed and cells stained with Hand E. ${ }^{25}$ Endothelin receptor subtypes were identified using $150 \mathrm{pM}^{125} \mathrm{I}$ PD151242 for $\mathrm{ET}_{\mathrm{A}}$ or ${ }^{125} \mathrm{I}$ BQ3020 for $\mathrm{ET}_{\mathrm{B}}$ (specific activity 2000 $\mathrm{Ci} / \mathrm{mM}$ for both (Nycomed Amersham)).

GROWTH UNDER THE INFLUENCE OF ET-1 AND ENDOTHELIN RECEPTOR ANTAGONISTS

Twenty thousand cells per well were plated into 24 well plates and grown for 24 hours in fully supplemented medium. The cells were washed and incubated in serum free medium containing $10^{-7}-10^{-12} \mathrm{M}$ ET-1/well for 48 or 72 hours. At each time point the cells were fixed in $10 \%$ formaldehyde and cell number measured using the methylene blue assay. ${ }^{26}$ The optimum concentrations of ET-1 for stimulation of growth from this experiment were used to investigate receptor antagonism.

$\mathrm{ET}_{\mathrm{A}}$ receptor antagonists $\mathrm{BQ} 123$ or BQ610 $(100 \mathrm{nM})$, or $\mathrm{ET}_{\mathrm{B}}$ receptor antagonist $\mathrm{BQ788}$ (100 $\mathrm{nM}$ ) were added to each well with or without ET-1 at $10^{-8} \mathrm{M}$ (LIM1215) or $10^{-9} \mathrm{M}$ (HT29). The plates were fixed with $10 \%$ formaldehyde at 48 and 72 hours; cell number was measured using the methylene blue assay.

\section{Results}

PRODUCTION OF ET-1 IN HUMAN COLORECTAL

CANCER CELLS

The production of ET-1 by the colorectal cell lines LIM1215 and HT29 was measured in media conditioned for 48 or 72 hours. Values were corrected for a baseline reading of 0.6 $\mathrm{fmol} / \mathrm{ml}$ (medium only). For LIM1215 there was only a small increase with time from 21.3 $\mathrm{fmol} / \mathrm{ml} / 10^{6}$ cells at 24 hours to $22.5 \mathrm{fmol} / \mathrm{ml} /$ $10^{6}$ cells at 48 hours. In contrast, HT29 secreted a higher concentration of ET-1 at 24 hours ( $41.7 \mathrm{fmol} / \mathrm{ml} / 10^{6}$ cells) which further increased to $71.7 \mathrm{fmol} / \mathrm{ml} / 10^{6}$ cells at 48 hours.

ENDOTHELIN RECEPTOR EXPRESSION IN HT29 AND LIM1215 COLORECTAL CANCER CELLS

Binding for ET-1, $\mathrm{ET}_{\mathrm{A}}$ antagonist (PD151242), and $\mathrm{ET}_{\mathrm{B}}$ agonist (BQ3020) in both cell lines was demonstrated by autoradiography. Total binding was clearly in excess of non-specific binding for ET-1 and its receptor subtypes for both LIM1215 and HT29 colorectal cancer cells, suggesting the presence of both receptors in these cell types (fig 1).
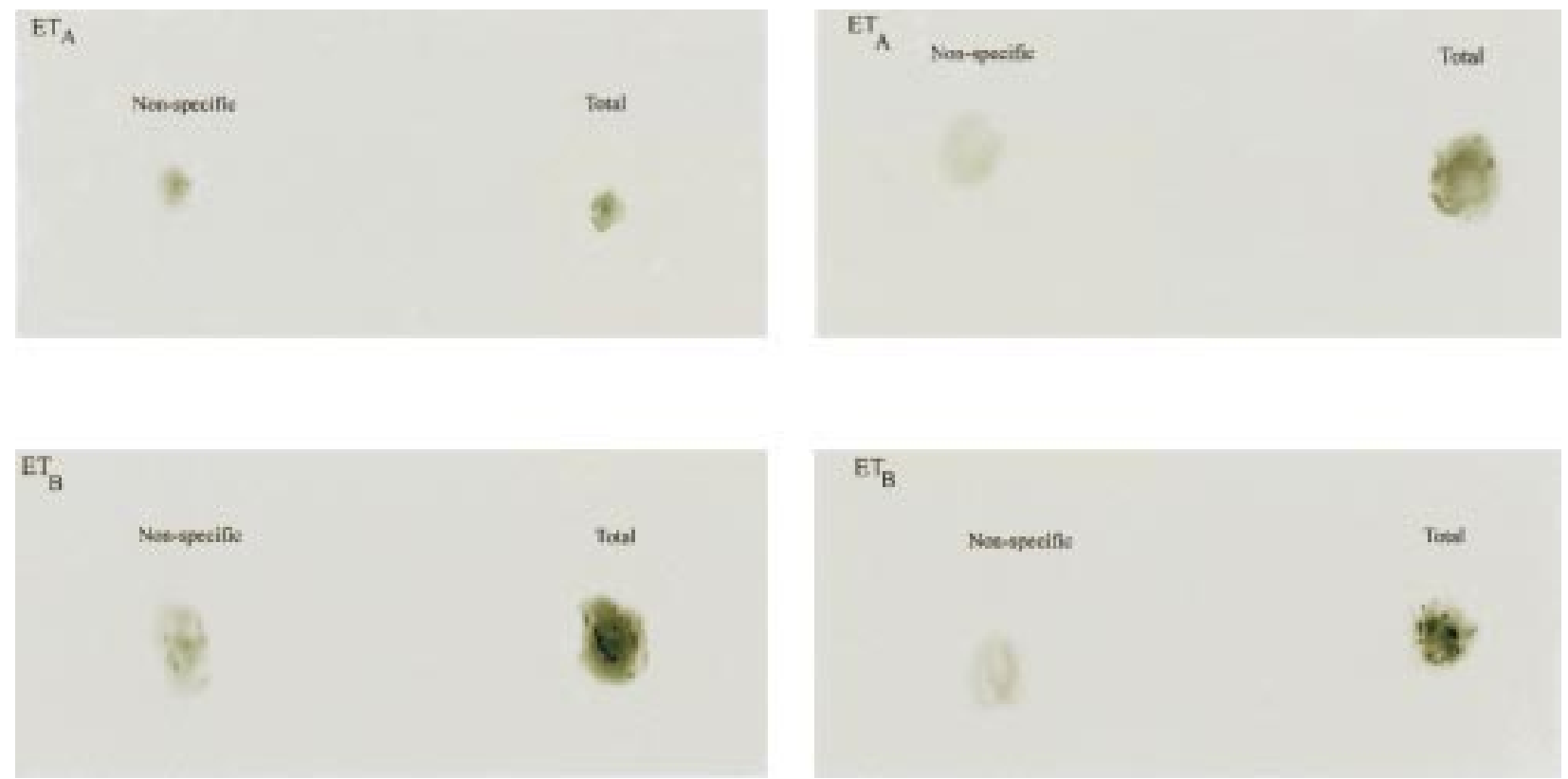

Figure 1 Binding for endothelin receptors (ET $T_{A}$ and $E T_{R}$ ) on LIM1215 (left) and HT29 (right) cell cytospins was demonstrated by autoradiography. Slides were incubated with $E T_{A}$ antagonist ( $\left(25\right.$ I PD151242) or ET $T_{B}$ agonist (25I BQ3020) for total binding. Non-specific binding was determined by incubation with excess unlabelled ligand. Total binding was clearly in excess of non-specific binding, suggesting the presence of both receptors in these cell types. 


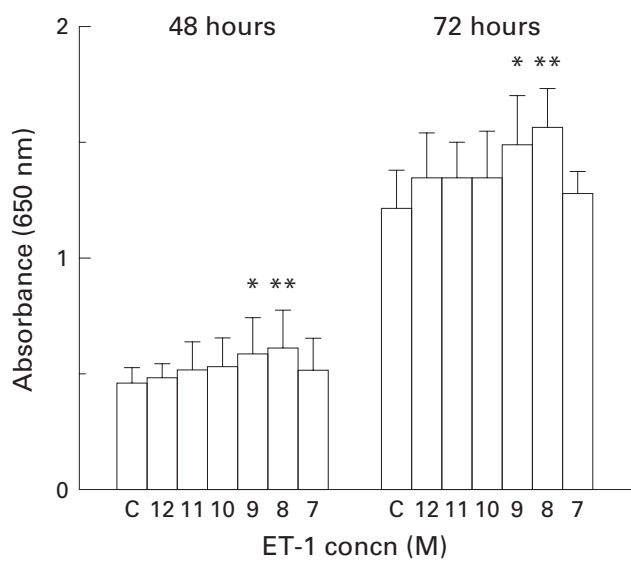

Figure 2 Effect of addition of endothelin 1 (ET-1) on LIM1215 cell growth. Cells were grown for 48 or 72 hours in the presence of increasing concentrations of ET-1 $\left(10^{-12}\right.$ $M$ to $10^{-7} \mathrm{M}$; shown on the $x$ axis as 12 to 7 ). Cell growth was measured using the methylene blue assay and read as absorbance (equivalent to cell numbers) at $650 \mathrm{~nm}$. Results are shown as mean (SD). Statistically significant growth is shown as ${ }^{\star} p<0.05$ or ${ }^{\star \star} p<0.01$ (Student's paired t test). C, control.

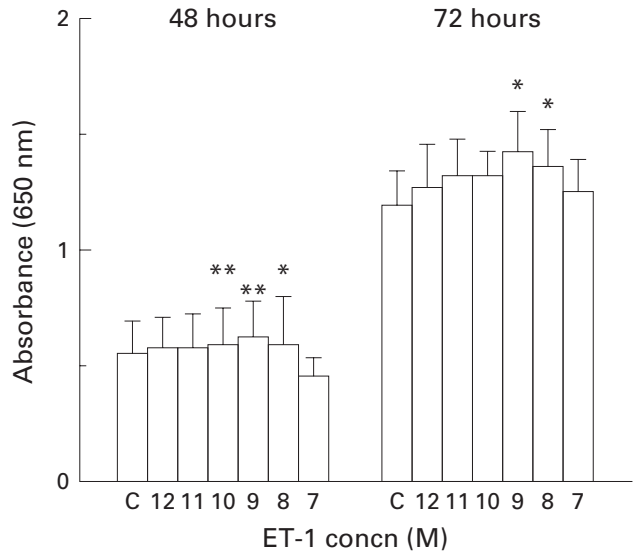

Figure 3 Effect of addition of endothelin 1 (ET-1) on HT29 cell growth. Cells were grown for 48 or 72 hours in the presence of increasing concentrations of ET-1 $\left(10^{-12} \mathrm{M}\right.$ to $10^{-7} \mathrm{M}$, shown on the $x$ axis as 12 to 7). Cell growth was measured using the methylene blue assay and read as absorbance (equivalent to cell numbers) at $650 \mathrm{~nm}$. Results are shown as mean (SD). Statistically significant cell growth is shown as ${ }^{\star} p<0.05$ or ${ }^{\star *} p<0.01$ (Student's paired t test). C, control.

EFFECT OF EXOGENOUS ADDITION OF ET-1 AND RESPONSE TO ET ${ }_{\mathrm{A}}$ AND $\mathrm{ET}_{\mathrm{B}}$ ANTAGONISTS Addition of ET-1 to both LIM1215 and HT29 resulted in a dose dependent increase in cell number (figs 2, 3). For LIM1215 this was maximal at $10^{-8} \mathrm{M}$ with a rise of $32.7 \%$ and $28.4 \%$ above controls at 48 and 72 hours, respectively. In contrast, the maximal number of cells for HT29 occurred with $10^{-9} \mathrm{M}$ ET-1 when there was an increase of $13.4 \%$ and $15.7 \%$ above control numbers at 48 and 72 hours, respectively.

Competitive $\mathrm{ET}_{\mathrm{A}}$ antagonists $\mathrm{BQ} 123$ and BQ610 significantly inhibited ET-1 induced proliferation of both LIM1215 and HT29 at 48 and 72 hours (figs 4,5). $\mathrm{ET}_{\mathrm{B}}$ antagonists had no effect on ET-1 stimulated proliferation.

\section{Discussion}

The effect of ET-1 on colorectal cancer cell growth was investigated in vitro. The two

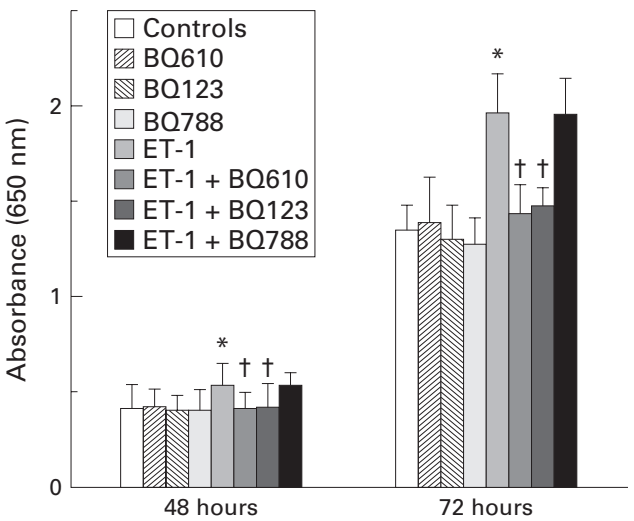

Figure 4 Effect of endothelin 1 (ET-1) and/or endothelin receptor antagonists on LIM1215 cell growth. Cells were grown for 48 or 72 hours in the presence of $10^{-8} M$ ET-1 and/or $E T_{A}$ receptor antagonist $B Q 123$ or $B Q 610$, or $E T_{B}$ receptor antagonist $B Q 788$, all at $100 \mathrm{nM}$. Cell growth was measured using the methylene blue assay and read as absorbance (equivalent to cell numbers) at $650 \mathrm{~nm}$. Results are shown as mean (SD). Cell numbers were significantly higher in the ET-1 group compared with control cells $\left({ }^{*} p<0.05\right.$, Student's $t$ test $)$; cell numbers from groups treated with both ET-1 and ET antagonists were similar to control levels, and were significantly lower than in the ET-1 group ( $t p<0.05$, Student's t test).

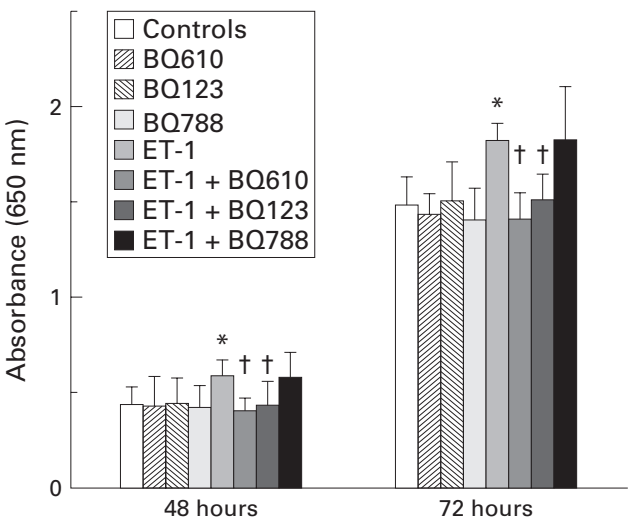

Figure 5 Effect of endothelin 1 (ET-1) and/or endothelin receptor antagonists on HT29 cell growth. Cells were grown for 48 or 72 hours in the presence of $10^{-9} \mathrm{M}$ ET-1 and/or $E T_{A}$ receptor antagonist $B Q 123$ or $B Q 610$, or $E T_{B}$ receptor antagonist $B Q 788$, all at $100 \mathrm{nM}$. Cell growth was measured using the methylene blue assay and read as absorbance (equivalent to cell numbers) at $650 \mathrm{~nm}$. Results are shown as mean (SD). Cell numbers were significantly higher in the ET-1 group compared with control cells $\left({ }^{*} p<0.05\right.$, Student's $t$-test); cell numbers from groups treated with both ET-1 and $E T_{A}$ antagonists were similar to control levels, and were significantly lower than in the ET-1 group ( $t p<0.05$, Student's t test).

colorectal cancer cell lines used in this study secreted ET-1, as has been demonstrated for other cancers. Levels of ET-1 measured in the medium were similar to those previously reported for HT29 of $23 \mathrm{fmol} / \mathrm{ml} / 10^{6}$ cells. $^{15}$

ET-1 acts via two receptors, $\mathrm{ET}_{\mathrm{A}}$ and $\mathrm{ET}_{\mathrm{B}}$, which were found to be present on LIM1215 and HT29 by autoradiography. This technique, by utilising radiolabelled agonists and antagonists which display high affinity for receptors, not only demonstrated the presence of the receptors but also indicated that they occurred in a functional state. ${ }^{27}$ Ovarian cancer cell lines have also been shown to produce ET-1 and express $\mathrm{ET}_{\mathrm{A}}$ and $\mathrm{ET}_{\mathrm{B}}$ receptors. ${ }^{18} 2829$

The mitogenic potential of exogenous ET-1 on these cell lines was assessed. This peptide 
was found to significantly increase cell number for both cell lines with a greater increase for LIM1215 compared with HT29. The difference may be related to the greater endogenous production of ET-1 by HT29: if the mitogenic effect occurs via one or both of the receptors and these receptors are partially occupied by endogenous ET-1, then addition of further ET-1 will have less of an effect than in a cell line where the receptors are available for binding. The concentrations of ET- $1\left(10^{-9} \mathrm{M}\right.$ and $\left.10^{-8} \mathrm{M}\right)$ which resulted in an increase in cell growth are 10000 times higher than circulating plasma levels of ET-1 in patients with colorectal cancer. However, locally (in tissues), much higher levels may occur. ${ }^{30}$ For other cell lines, for example Swiss 3T3 fibroblasts, vascular smooth muscle, and ovarian cancer cell lines, a mitogenic effect of ET-1 was produced at $10^{-10} \mathrm{M}$, only 10 -fold lower than that required to produce an effect on LIM1215 and HT29. ${ }^{5-7} 18$

The effect of ET-1 on LIM1215 and HT29 was mediated via the $\mathrm{ET}_{\mathrm{A}}$, and not the $\mathrm{ET}_{\mathrm{B}}$ receptor, as demonstrated by the ability of BQ123 and BQ610 to prevent an increase in cell number on addition of ET-1. $\mathrm{ET}_{\mathrm{A}}$ has also been demonstrated to be the receptor through which the mitogenic effect of ET-1 is mediated for ovarian cancer cell lines ${ }^{18}$ and for a number of other cell lines. ${ }^{56930}$ In contrast, BQ788, the $\mathrm{ET}_{\mathrm{B}}$ antagonist, had no effect on cell number.

In the only in vitro cancer model in which ET-1 mitogenic signalling has been studied, ovarian cancer cells were used. Binding of ET-1 to the $\mathrm{ET}_{\mathrm{A}} \mathrm{G}$ protein coupled receptor resulted in activation of phospholipase $\mathrm{C}$ activity and $\mathrm{Ca}^{2+} /$ PKC signalling, which are the classical effectors of $\mathrm{G}$ protein signalling. Furthermore, other intracellular targets activated included: tyrosine kinases (for example, focal adhesion kinase $\left.\mathrm{p} 125^{\mathrm{FAK}}\right), \mathrm{p} 42$ mitogen activated protein kinase (MAPkinase), and immediate early response genes (for example, fos). ${ }^{28}$ This suggests that ET-1 not only uses phospholipase $\mathrm{C} / \mathrm{PKC}$ pathways but cross talks with tyrosine kinase cascades. These intracellular steps have been implicated in mitogenic signalling via $\mathrm{ET}_{\mathrm{A}}$ in a variety of cell types, including fibroblasts and vascular smooth muscle cells. ${ }^{30-34}$

In conclusion, ET-1 can stimulate net cell growth of LIM1215 and HT29 colorectal cancer cell lines via the $\mathrm{ET}_{\mathrm{A}}$ receptor. Whether this effect is mediated via a mitogenic stimulus as in ovarian cancer cells and other non-cancer cells, or an anti-apoptotic signal, or a combination of the two, has not yet been demonstrated in this model. However, the findings of Asham and colleagues $^{19}$ and Shankar and colleagues ${ }^{20}$ that ET-1 is produced by colorectal cancers combined with the data from this study are consistent with the notion that ET-1 may act as a mitogen in colorectal cancer and that there may be some therapeutic potential in the use of $\mathrm{ET}_{\mathrm{A}}$ antagonists.

1 Inoue $\mathrm{A}$, Yanagisawa $\mathrm{M}$, Kimura $\mathrm{S}$, et al. The human endothelin family: three structurally and pharmacologically distinct isopeptides predicted by three separate genes. Proc Natl Acad Sci USA 1989;86:2863-7.

2 Arai H, Nori S, Aramori I, et al. Cloning and expression of a cDNA encoding an endothelin receptor. Nature 1990;348: cDNA
3 Sakurai T, Yanagisawa $M$, Takuwa $\mathrm{Y}$, et al. Cloning of a cDNA encoding a non-isopeptide selective subtype of the cDNA encoding a non-isopeptide selective s

4 Yanagisawa M, Kurihara H, Kimura S, et al. A novel potent vasoconstrictor peptide produced by vascular endothelial cells. Nature 1989;332:411-15.

5 Kusuhara M, Yamanguchi K, Ohnishi A, et al. Endothelin potentiates growth factor stimulated DNA synthesis in Swiss 3 T 3 cells. F Cancer Res 1989;80:302-5.

6 Komuro I, Kurihara H, Sugiyama T, et al. Endothelin stimulates c-fos and c-myc expression and proliferation of
vascular smooth muscle cells. FEBS Lett 1988;238:249-52.

7 Nakaki T, Nakayama M, Yamamoto S, et al. Endothelin mediated stimulation of DNA synthesis in vascular smooth muscle cells. Biochem Biophys Res Commun 1989;158:880-3.

8 Giaid A, Hamid QA, Springall DR. Detection of endothelin immunoreactivity and mRNA in pulmonary tumours. $\mathcal{F}$ Pathol 1990;162:15-22.

9 Yamashita J, Ogawa M, Egami $\mathrm{H}$, et al. Abundant expression of immunoreactive endothelin-1 in the growth of stromal cells in phyllodes tumour. Cancer Res 1992;52: 406-9.

10 Kojima K, Nihei Z. Expression of endothelin-1 immunoreactivity in breast cancer. Surg Oncol 1995;4:309-15.

11 Ishibashi M, Fujita M, Nagai K, et al. Production and secretion of endothelin by hepatocellular carcinoma. $\mathcal{f}$ Clin Endocrinol Metab 1993;76:378-83.

12 Nelson BJ, Chan-Tack K, Hedican SP, et al. Endothelin-1 production and decreased endothelin B receptor expression in advanced prostate cancer. Cancer Res 1996;56:663-8.

13 Kusuhara M, Yamanguchi K, Nagasaki K, et al. Production of endothelin in human cancer cell lines. Cancer Res 1990; 50:3257-61.

14 Oikawa T, Kusuhara M, Ishikawa S, et al. Production of endothelin-1 and thrombomodulin by human pancreatic cancer cells. F Cancer 1994;69:1059-64.

15 Baley PA, Resink TJ, Eppinberger U, et al. Endothelin messenger RNA and receptors are differentially expressed in cultured human breast epithelial and stromal cells. $\mathcal{f}$ Clin Invest 1990;85:1320-3.

16 Mathieu MN, Chevillard C. Endothelin-1 and subtypes are expressed in the gastric HGT-1 cell line. 7 Cardiovasc Pharmacol 1995;26:S508-9.

17 Shichiri M, Hirata Y, Nakajima T, et al. Endothelin-1 is an autocrine/paracrine growth factor for human cancer cell lines. F Clin Invest 1991;87:1867-71.

18 Moraitis S, Langdon SP, Miller WR. Endothelin expression and responsiveness in human ovarian carcinoma cell lines. Eur f Cancer 1997;33:661-8.

19 Asham E, Loizidou M, Lakhani S, et al. Expression of endothelin-1 in 98 patients with colorectal cancer. Eur $\mathcal{F}$ Surg Oncol 1998;23:589.

20 Shankar A, Loizidou M, Aliev G, et al. Elevated endothelin-1 levels in patients with colorectal liver metastases. Br f Surg 1998;85:502-6.

21 Asham E, Shankar A, Loizidou M, et al. Production and secretion of endothelin-1 in colorectal cancer. Br $\mathcal{F}$ Surg 1997;84:1596.

22 Inagaki $\mathrm{H}$, Bishop $\mathrm{AE}$, Eimoto $\mathrm{T}$, et al. Localisation of endothelin-like immunoreactivity and endothelin binding sites in human colon. Gastroenterology 1991;101:47-54.

23 Inagaki H, Bishop AE, Eimoto T, et al. Autoradiographic localisation of endothelin-1 binding sites in human colonic cancer tissue. F Pathol 1992;168:263-7.

24 Inagaki $\mathrm{H}$, Bishop AE, Yura J, et al. Localisation of endothelin-1 and its binding sites in the nervous system of the human colon. F Cardiovasc Pharmacol 1991;17:S455-7.

25 Dashwood MR, Timm M, Muddle JR, et al. Regional variations in endothelin-1 and its receptor subtypes in human coronary vasculature: pathophysiological implications in coronary vasculature: pathophysiological impl

26 Oliver MH, Harrison NK, Bishop JE, et al. A rapid and convenient assay for counting cells cultured in microwell plates: Application for assessment of growth factors. $\mathcal{F}$ Cell Sci 1989;92:513-18.

27 Dashwood M, Timm M, Kaski JC. Regional variations in $\mathrm{ET}_{\mathrm{A}} / \mathrm{ET}_{\mathrm{B}}$ binding sites in human coronary vasculature. $\mathcal{F}$ Cardiovasc Pharmacol 1995;26:S351-4.

28 Bagnato A, Tecce R, Di Castro V, et al. Activation of mitogenic signaling by endothelin-1 in ovarian carcinoma cells. Cancer Res 1997;57:1306-11.

29 Bagnato A, Salani D, Di Castro V, et al. Expression of ET-1 and $\mathrm{ET}_{\mathrm{A}}$ receptor in ovarian carcinoma: evidence for an and $\mathrm{ET}_{\mathrm{A}}$ receptor in ovarian carcinoma: evidence for an

30 Walden PD, Ittmann M, Monaco ME, et al. Endothelin-1 production and agonist activities in cultured prostate derived cells: implications for regulation of endothelin bioactivity and bioavailability in prostatic hyperplasia. Prostate 1998;34:241-50

31 Saville MK, Graham A, Malarkey K, et al. Regulation of ET-1 and lysophosphatidic acid stimulated tyrosine phosphorylation of focal adhesion kinase in Rat-1 fibroblasts. Biochem f 1994;301:407-14.

32 Fujitami Y, Ninomiya H, Okada T, et al. Suppression of ET-1 induced mitogenic responses of human aortic smooth muscle cells by interleukin-1 $\beta$. F Clin Invest 1995;95:247482 .

33 Luttrell LM, Daaka Y, Lefkowitz J. Regulation of tyrosine kinase cascades by G-protein-coupled receptors. Curr Opin Cell Biol 1999;11:177-83.

34 Schwartz MA, Baron V. Interactions between mitogenic stimuli, or, a thousand and one connections. Curr Opin Cell Biol 1999;11:184-9. 